\title{
The Surface Roughness and Gloss of Composites
}

\author{
W. J. O'BRIEN, W. M. JOHNSTON, F. FANIAN, and S. LAMBERT
}

School of Dentistry, University of Michigan, Ann Arbor, Michigan 48109

The contrast gloss and the average roughness were measured for four commercial composite filling materials. Using a factorial design, each material was subjected to four available finishing methods. A significant difference was found in the contrast gloss among finish. ing methods, and a significant linear regression is given which relates the inverse of the contrast gloss to the average roughness. Surface gloss is proposed as playing a major role in the esthetic appearance of composite restorations.

\section{J Dent Res 63(5):685-688, May 1984}

\section{Introduction.}

The roughness produced by different finishing methods has been reported by several investigators (Johnson et al., 1971; Dennison and Craig, 1972; Glantz and Larson, 1972; Tolley et al., 1978). Although smoother surfaces are achieved when the composite is cured in contact with a Mylar strip, additional contouring and finishing with burs, stones, and finishing disks are usually necessary. A previous study (Dennison et al., 1981) has also found lower roughness values achieved with submicron-sized silica particles. The purpose of this investigation was to study the relation between the surface roughness and gloss of composite materials with different filler systems.

\section{Materials and methods.}

The four composite materials studied were those which used a filler of conventional coarse filler particles*, a mixture of conventional particles and colloidal silica ${ }^{t}$, small particles in the $\mu \mathrm{m}$ range $\ddagger$, and a mixture of colloidal silica and ground polymer $\S$. The materials were handled according to manufacturers' instructions and were packed into a cavity $2 \mathrm{~cm} \times 1 \mathrm{~cm} \times 2 \mathrm{~mm}$ in an aluminum mold. During setting, the composite surfaces were covered with a Mylar strip, and a glass slide was then clamped into place. The following finishing methods were used for each material according to a factorial design: 12-fluted bur , 600-grit alumina disk $^{\bullet}$, silicon carbide fine disk ${ }^{\#}$, and a rubberabrasive composite finishing wheel**. Duplicate samples were made for each cell of the factorial design.

Roughness was measured with a surfanalyzer. ${ }^{\dagger} \dagger$ Surface profile tracings were obtained with the diamond stylus

Received for publication April 5, 1983

Accepted for publication December 5, 1983

This investigation was supported in part by USPHS Research Grant DE-05423 from the National Institute of Dental Research, National Institutes of Health, Bethesda, MD 20205.

*Concise, 3M Co., St. Paul, MN, base H24A, catalyst BIJ51

† Miradapt, J \& J Dental Products Co., Twin Rivers, NJ, batch \#OE902

$\Varangle$ Command Ultrafine, Kerr Mfg. Co., Romulus, MI, batch \#20685

\$ Silar, 3M Co., St. Paul, MN, batch \#H24a, catalyst B-1 V2

I American Midwest FG7901, Des Plaines, IL 60018

-3M Co., St. Paul, MN, Batch 1958F

\#F.C. Moore Co., Bearborn, MI 48216

**Identoflex, $1002 \mathrm{CB}$, Buchs, Switzerland

† Surfanalyzer, Clevite Corp., Gaging and Control Div., El Monte, CA 91731, drive Model 21-1410-01 with 21-3100-00 probe, control Model 21-1330-20, and recorder Model 15-6327-20 moving at a speed of $0.25 \mathrm{~mm} / \mathrm{sec}$. Arithmetic average surface roughness values were obtained from the tracings. Differences among roughness values were statistically examined using analysis of variance, with pairwise comparisons by the method of Student-Newman-Keuls (Sokal and Rohlf, 1969).

Surface gloss is the optical property that produces a lustrous appearance (Hunter, 1975). There are several recognized gloss properties, including specular gloss, sheen, luster, and distinctness-of-image gloss. In this study, contrast gloss or luster was measured. Contrast gloss is the proportion of specular reflection to diffuse reflection. These reflections are schematically presented in Fig. 1 for both high and low gloss. A goniophotometer $\ddagger$ was used to measure contrast gloss, using incident tungsten light at an angle of $60^{\circ}$ from the normal to the surface. The ratio of specular reflection at an angle of $60^{\circ}$ to that reflected normal to the surface was measured for the finished composite samples, as diagrammed in Fig. 2. Statistical evaluation of the gloss values was obtained by analysis of variance as above. Regression analysis was used to determine a relationship between gloss and roughness. The regression was attempted with contrast gloss and with the inverse of contrast gloss as the dependent variable. Representative finished surfaces were studied with scanning electron microscopy.

\section{Results.}

The means and the analyses of variance for the average roughness values for the composite materials and the finishing methods are given in Table 1. Pairwise comparisons demonstrated that the composite with the conventional coarse filler particles finished with the 12-fluted bur gave a significantly greater roughness than did any other composite-finishing method combination. The composites with the filler mixture of conventional coarse particles and the colloidal silica and with the filler of small particles in the $\mu \mathrm{m}$ range finished with the 12-fluted bur then resulted in roughness values which were higher than any remaining composite-finishing method combination.

The means and the analyses of variance for the contrast gloss values are given in Table 2 . The average gloss value for all of the composite materials studied is significantly greater using the rubber-abrasive composite wheel than for any

$\ddagger \ddagger$ Differential I, Science Spectrum, Santa Barbara, CA
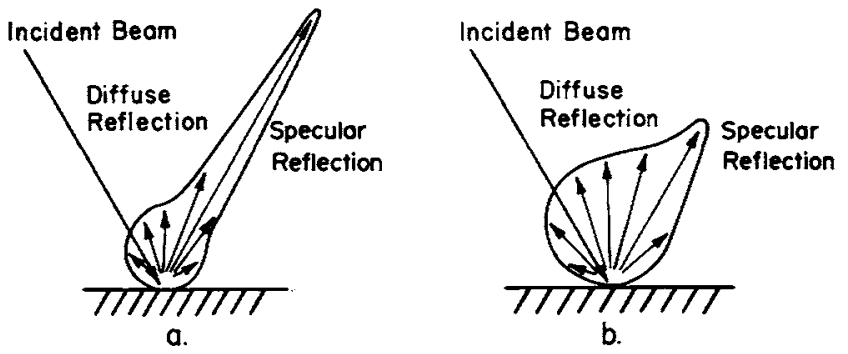

Fig. 1 - Schematic diagram of diffuse and specular reflection. a. High gloss. b. Low gloss. 


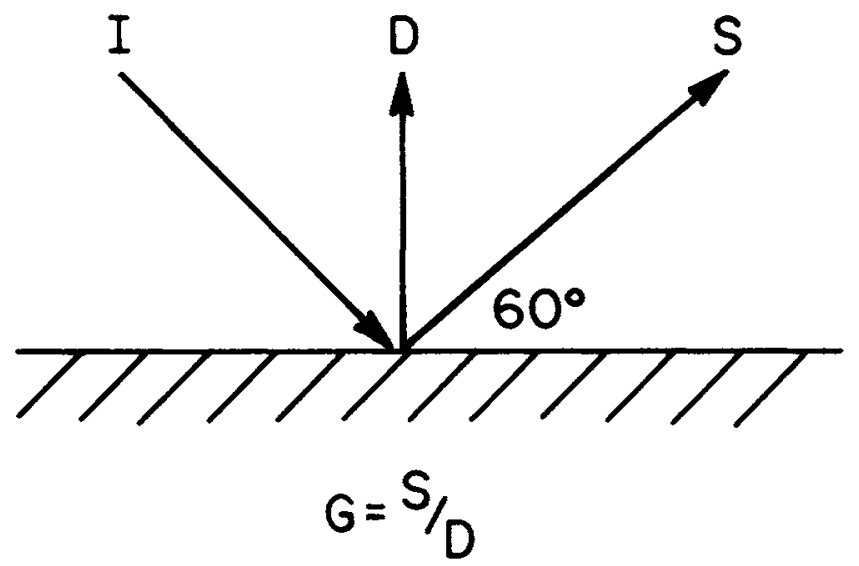

Fig. 2 - Contrast gloss as the ratio of specular reflection at $60^{\circ}$ to diffuse reflection at $90^{\circ}$.

TABLE 1

MEAN VALUES AND ANALYSIS OF VARIANCE FOR ARITHMETIC AVERAGE ROUGHNESS (in $\mu \mathrm{m}$ )

\begin{tabular}{|c|c|c|c|c|}
\hline \multicolumn{5}{|c|}{ Mean Values $(n=2)$} \\
\hline \multicolumn{5}{|c|}{ Finishing Method } \\
\hline Filler & $\begin{array}{c}\text { 12-fluted } \\
\text { Bur }\end{array}$ & $\begin{array}{c}\text { (600-grit) } \\
\text { Alumina } \\
\text { Disk }\end{array}$ & $\begin{array}{c}\mathrm{SiC} \\
\text { (fine) } \\
\text { Disk }\end{array}$ & $\begin{array}{c}\text { Rubber- } \\
\text { Abrasive } \\
\text { Composite } \\
\text { Wheel }\end{array}$ \\
\hline $\begin{array}{l}\text { Conventional } \\
\text { Coarse }\end{array}$ & 1.50 & 0.38 & 0.32 & 0.30 \\
\hline $\begin{array}{l}\text { Mix of Coarse } \\
\text { and Colloidal } \\
\text { Silica }\end{array}$ & 0.98 & 0.17 & 0.31 & 0.45 \\
\hline $\begin{array}{l}\text { Small }(\mu \mathrm{m}) \\
\text { Particles }\end{array}$ & 0.33 & 0.08 & 0.38 & 0.25 \\
\hline $\begin{array}{l}\text { Mix of Colloidal } \\
\text { Silica and } \\
\text { Ground Polymer }\end{array}$ & 0.98 & 0.14 & 0.45 & 0.08 \\
\hline \multicolumn{5}{|c|}{ Analysis of Variance } \\
\hline $\begin{array}{l}\text { Source of } \\
\text { Variation }\end{array}$ & $\begin{array}{l}\text { Degrees of } \\
\text { Fieedom }\end{array}$ & $\begin{array}{l}\text { Mean } \\
\text { Sum of } \\
\text { Squares }\end{array}$ & F-ratio & $\begin{array}{l}\text { Statistical } \\
\text { Probability }\end{array}$ \\
\hline $\begin{array}{l}\text { Among Subgroups } \\
\text { Finishing Method } \\
\text { Filler } \\
\text { Interaction } \\
\text { Residual (error) }\end{array}$ & $\begin{array}{r}15 \\
3 \\
3 \\
9 \\
16\end{array}$ & $\begin{array}{l}0.298 \\
0.936 \\
0.187 \\
0.122 \\
0.024\end{array}$ & $\begin{array}{r}12.35 \\
38.82 \\
7.75 \\
5.06\end{array}$ & $\begin{array}{l}<0.001 \\
<0.001 \\
<0.005 \\
<0.010\end{array}$ \\
\hline
\end{tabular}

other finishing method studied. When values are compared within subgroups, the average gloss values for the composites with fillers of small particles in the $\mu \mathrm{m}$ range and of the mix of colloidal silica and ground polymer when polished with the rubber-abrasive composite wheel are significantly greater than that for any composite material studied, finished using the alumina or silicon carbide disks, or for the composites with fillers of conventional particles, of a mixture of coarse particles and colloidal silica, or of a mixture of colloidal silica and ground polymer when finished with the 12-fluted bur.

The linear regression which produced the greater agree-
TABLE 2

MEAN VALUES AND ANALYSIS OF VARIANCE FOR CONTRAST GLOSS

\begin{tabular}{|c|c|c|c|c|}
\hline \multicolumn{5}{|c|}{ Mean Values $(n=2)$} \\
\hline \multicolumn{5}{|c|}{ Finishing Method } \\
\hline Filler & $\begin{array}{l}\text { 12-fluted } \\
\text { Bur }\end{array}$ & $\begin{array}{c}\text { (600-grit) } \\
\text { Alumina } \\
\text { Disk }\end{array}$ & $\begin{array}{l}\mathrm{SiC} \\
\text { (fine) } \\
\text { Disk }\end{array}$ & $\begin{array}{l}\text { Rubber- } \\
\text { Abrasive } \\
\text { Composite } \\
\text { Wheel }\end{array}$ \\
\hline $\begin{array}{l}\text { Conventional } \\
\text { Coarse }\end{array}$ & 1.9 & 5.0 & 4.9 & 8.5 \\
\hline $\begin{array}{l}\text { Mix of Coarse } \\
\text { and Colloidal } \\
\text { Silica }\end{array}$ & 2.4 & 5.2 & 4.6 & 8.8 \\
\hline $\begin{array}{l}\text { Small (micron) } \\
\text { Particles }\end{array}$ & 7.9 & 5.9 & 4.1 & 11.7 \\
\hline $\begin{array}{l}\text { Mix of Colloidal } \\
\text { Silica and } \\
\text { Ground Polymer }\end{array}$ & 3.3 & 4.1 & 4.1 & 12.2 \\
\hline $\begin{array}{l}\text { Mean for four } \\
\text { composite } \\
\text { materials } \\
(n=8)\end{array}$ & 3.9 & 5.0 & 4.4 & 10.3 \\
\hline \multicolumn{5}{|c|}{ Analysis of Variance } \\
\hline $\begin{array}{l}\text { Source of } \\
\text { Variation }\end{array}$ & $\begin{array}{l}\text { Degrees of } \\
\text { Freedom }\end{array}$ & $\begin{array}{c}\text { Mean } \\
\text { Sum of } \\
\text { Squares }\end{array}$ & F-ratio & $\begin{array}{l}\text { Statistical } \\
\text { Probability }\end{array}$ \\
\hline $\begin{array}{l}\text { Among Subgroups } \\
\text { Finishing Method } \\
\text { Filler } \\
\text { Interaction } \\
\text { Residual (error) }\end{array}$ & $\begin{array}{r}15 \\
3 \\
3 \\
9 \\
16\end{array}$ & $\begin{array}{r}18.90 \\
70.47 \\
8.84 \\
5.06 \\
3.19\end{array}$ & $\begin{array}{r}5.93 \\
22.10 \\
2.77 \\
1.59\end{array}$ & $\begin{array}{l}<0.001 \\
<0.001 \\
>0.05 \\
>0.10\end{array}$ \\
\hline
\end{tabular}

ment was that with the inverse of gloss as the dependent variable. The linear relation was found to be:

$$
\frac{1}{G}=0.27 R+0.099
$$

where $G$ represents contrast gloss, and $R$ represents the arithmetic average roughness in $\mu \mathrm{m}$. The regression coefficient was found to be significantly greater than zero at $\mathbf{P}<0.001$.

Fig. 3 is a scanning electron micrograph of the composite with small filler particles in the $\mu \mathrm{m}$ range finished with the rubber-abrasive composite wheel. Fig. 4 is a micrograph of the composite with the conventional filler finished with the 12-fluted bur. Fig. 5 gives the polar reflectance diagrams for these two surfaces.

\section{Discussion.}

Analysis of these data indicates that high gloss surface finishes were obtained with the microfilled and the $\mu \mathrm{m}$ sized particle filler composites. It had been presumed that only microfilled composites could be finished to provide highly smooth surfaces (Raptis et al., 1979).

The correlation between the roughness and the inverse of the contrast gloss is also an interesting finding. Gloss is an important appearance property of composite restorations that has not previously been studied. Differences in gloss between a restoration and surrounding tooth enamel are significant for two reasons. First, the eye will detect 


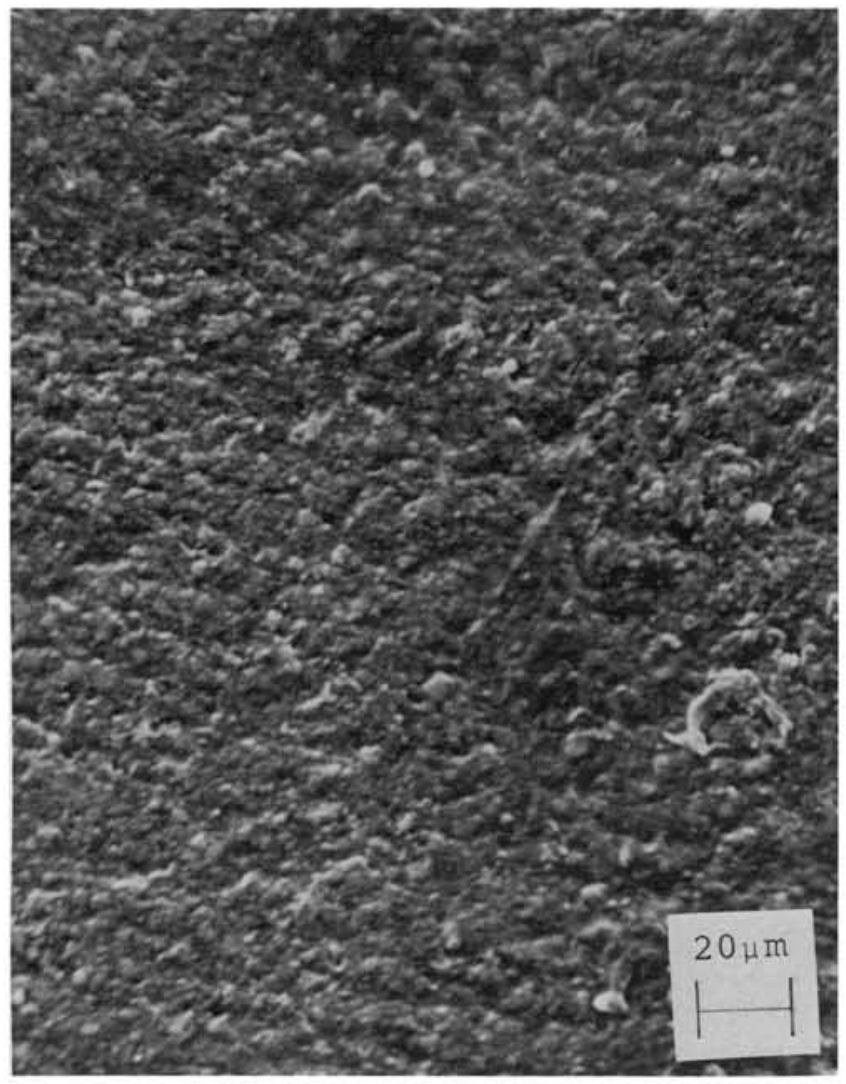

Fig. 3 - Scanning electron micrograph of the composite with small filler particles in the micron range finished with the rubberabrasive composite wheel.

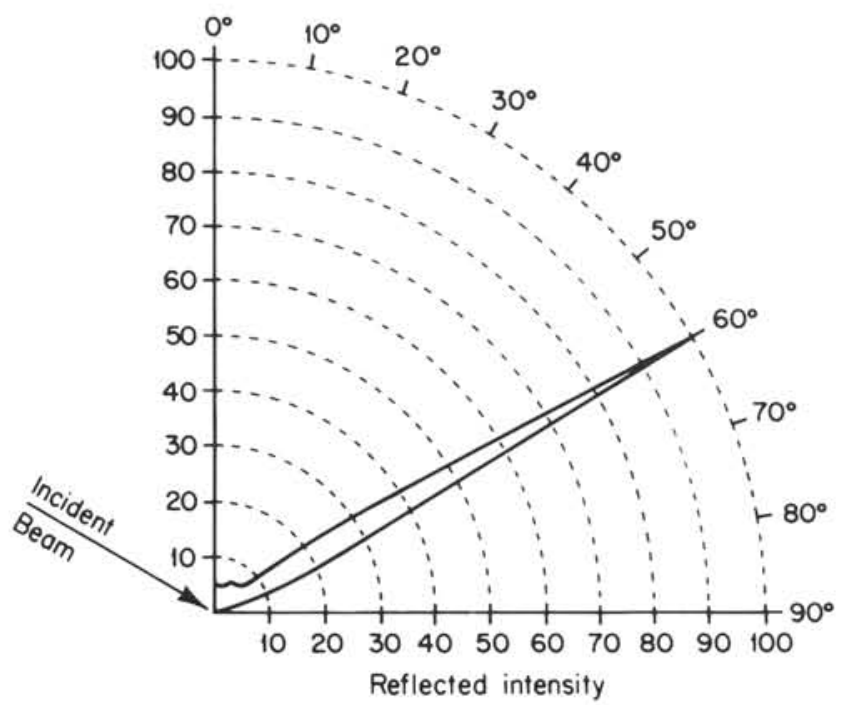

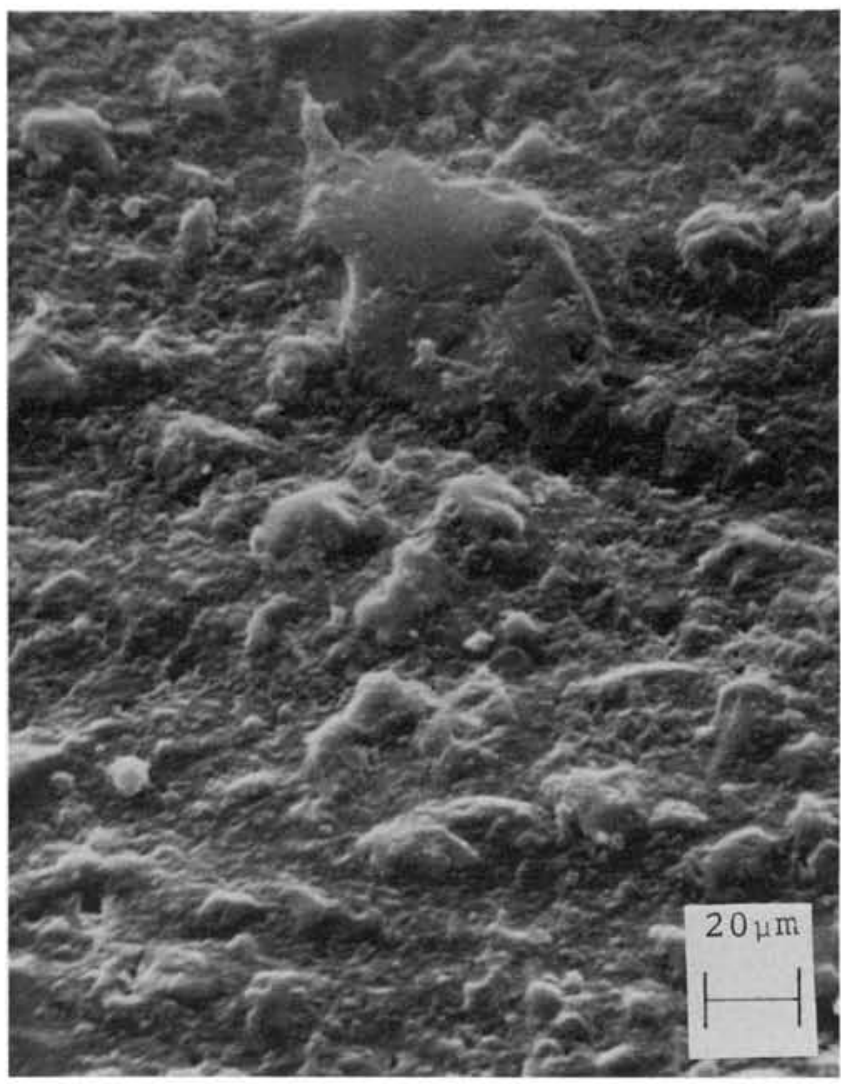

Fig. 4 - Scanning electron micrograph of the composite with the conventional filler finished with the 12 -fluted bur.

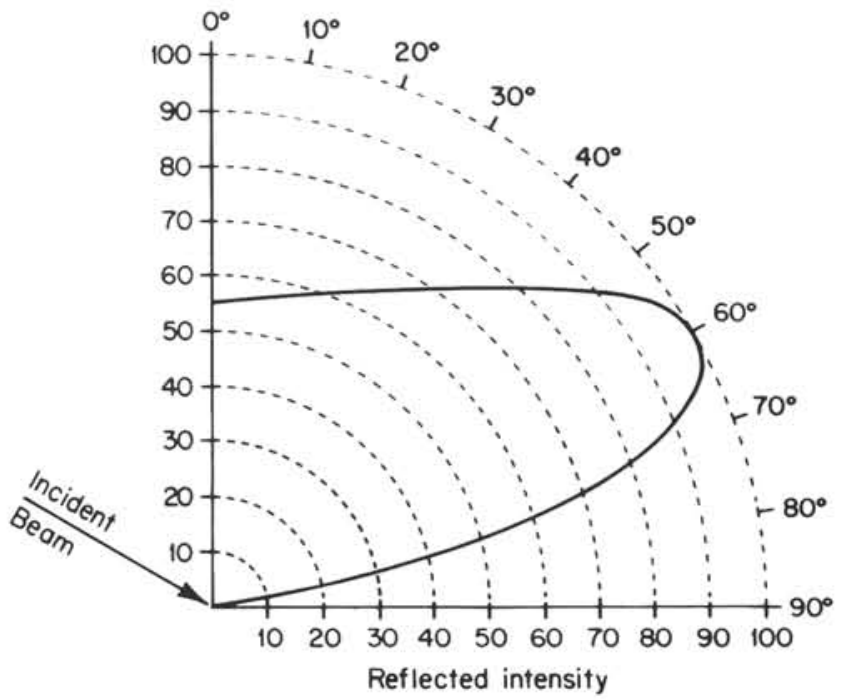

Fig. 5 - Polar reflectance diagrams. a. The composite with small filler particles in the $\mu \mathrm{m}$ range finished with the rubber-abrasive composite wheel. $\mathrm{b}$. The composite with the conventional filler finished with the 12-fluted bur.

differences in gloss between a composite and the surrounding enamel, even if their colors are matched. Also, high gloss reduces the effect of a color difference, since the color of reflected light is predominant rather than the color of the underlying composite material. Therefore, color matching booths correctly employ only diffuse illumination to eliminate specular reflection. Thus, high gloss is an important asset of a composite material for matching tooth structure, particularly since only a few shades are available for a given brand of composite for matching a wide variety of tooth shades. The higher gloss of the composite materials when finished with the rubber-abrasive composite wheel would appear to be an advantage over the other finishing methods studied in matching surrounding tooth structure after insertion, assuming the same shade was used. 


\section{REFERENCES}

DENNISON, J.B. and CRAIG, R.G.: Effects of Various Finishing Devices on Resin Surfaces, JADA 83:321-331, 1971.

DENNISON, J.B.; FAN, P.L.; and POWERS, J.M.: Surface Roughness of Microfilled Composites, JADA 102:859-862, 1981.

GLANTZ, P.-O. and LARSON, L.A.: Surface Roughness of Composite Resins Before and After Finishing, Acta Odontol Scand 30:101-108, 1972.

HUNTER, R.S.: The Measurement of Appearance, New York: Wiley, 1975 , pp. 65-77.
JOHNSON, L.N.; JORDAN, R.E.; and LYNN, J.A.: Effects of Various Finishing Devices on Resin Surfaces, JADA 83:321-331, 1971.

SOKAL, R.R. and ROHLF, F.J.: Biometry, San Francisco: W.H. Freeman \& Co., 1969, pp. 239-246.

RAPTIS, C.N.; FAN, P.L.; and POWERS, J.M.: Properties of Microfilled and Visible Light-Cured Composite Resins, JADA 99:631633, 1979.

TOLLEY, L.G.; O'BRIEN, W.J.; and DENNISON, J.B.: Surface Finish of Dental Composite Restorative Materials, J Biomed Mater Res 12:233-240, 1978.

\section{PROGRAM ANNOUNCEMENT}

International Conference on Oral Metallic Interactions:

The Measurement and Consequences of Tarnish and Corrosion of Dental Materials

Tentative Topics on the Program

Defining the Oral Environment

Local and Systemic Response to Corrosion Phenomena

Toxicity, Hypersensitivity, Carcinogenicity, and Morbidity to Corrosion Products

Electrochemical Equilibria and the Galvanic Series

Corrosion Testing, Surface Optical, and Microstructural Defects

The ANSI Task Group on Tarnish and Corrosion

In Vitro/In Vivo Correlation and Prediction of Corrosion Behavior

Open Session for informal presentations by attendees, participants, and discussants

\section{Scheduled Speakers}

Maude Bergman, Univ. of Ume\&

Simon Civjan, Univ. of Texas

J. David Eick, Oral Roberts Univ.

Graeme Ewers, Univ. of West. Australia

Randall German, Rensselaer

Per-Olaf Glantz, Univ. of Lund

Clyde Ingersoll, Williams Gold

John Keller, Med. Univ. S. Carolina

Karl Leinfelder, Univ. of Alabama

Jack Lemons, Univ. of Alabama
Linda Lucas, Univ. of Alabama Miroslav Marek, Georgia Tech. Jean-Marc Meyer, Univ. of Geneva Sheldon Newman, Univ. of Alberta Marcel Pourbaix, Belgian Cent. Corr. Studies Brussels

Nikhil Sarkar, LSU Sch. of Dentistry

Dennis Smith, Univ. of Toronto

T.K. Vaidyanathan, NYU Coll. of Dentistry

D.H. Williams, Univ. of Liverpool

Lawrence Gettleman, Gulf South Research Institute, P.O. Box 26518, New Orleans, LA 70186-6518

Program Chairperson (504)283-4223

October 18-20, 1984 Callaway Gardens, Georgia

(Just prior to ADA Meeting) 